Karolina Kotulewicz

Department of Political Science

Cracow University of Economics, Poland

Małgorzata Kozłowska

Department of Tourism and Regional Research

Pedagogical University of Cracow, Poland

\title{
TOURISM AS THE PRIORITY FOR THE ECONOMIC DEVELOPMENT OF MODERN GEORGIA
}

\section{Abstract}

Georgia has taken a growing interest in reviving and developing tourism since the late 1990s. The country's considerable tourist assets make this a valid choice of direction for the country's economic growth. The paper aims to show the role and significance of tourism in contemporary Georgia. The authorities, who also noted the sector's importance as a factor of political and international integration, have regarded its development as a main pathway for the state's economic growth since 2000. It can be seen in the performance of the sector, which has been making a considerable contribution to Georgia's GDP since the beginning of the century, that the strategy has been successful.

Keywords: Georgia, tourism, economic growth, development of tourism.

\section{Introduction}

Tourism plays an important role in the economic development of many countries. It encourages the conservation of cultural traditions, favours the promotion of national cultural values, and fosters the creation of a positive image. What is more, it is also a significant factor in political and international integration.

Georgia, which is a democratic, semi-presidential republic, is a small country with a population of $4,483,800$ and a territory of only $69,700 \mathrm{~km}^{2}$ 
(Geostat 2014). It lies in south-eastern Europe and is bordered by the Black Sea to the west, Russia in the north and east, Azerbaijan in the east and south, and Armenia and Turkey to the south.

Georgia, which is amply blessed in this respect, selected tourism as a target for economic revival and development at the turn of the $21^{\text {st }}$ century. In addition to its rich cultural resources, it is almost unique among the world's nations when it comes to biodiversity. It has the rare advantage of being able to offer subtropical marshes, semi-deserts, lofty alpine zones and snowy peaks within a hundred kilometres of each other.

Given the Georgian government's designation in 2000 of tourism as essential to economic growth, the article aims to assess the sector's contribution to the country's economic development.

\section{The Economic Development of Modern Georgia}

Modern Georgia is a developing country that for the majority of the $20^{\text {th }}$ century operated an adapted form of the Soviet planned economy, but after gaining independence in 1991 it began a transition to a market economy. The change of economic system was not an easy one, which was demonstrated by the republic's terrible macroeconomic situation. Annual decreases in GDP, which were a feature throughout the 1980s, culminated in a fall of $20 \%$ in 1991 (Mitręga \& Pietrucha 2004). The first three years of independence saw no reversal of this trend. Georgia's GDP in 1992 was only $44.1 \%$ of that in 1990, in 1993 only $29.4 \%$ of that in 1990, and in 1994 only 20.6\% of that in 1990 (Wiellisz 1996). The crisis almost destroyed the transport and construction sectors, whose produced value fell to a level of a few per cent of the base-year value, and instigated a deep recession in the energy industry, where production in 1994 was barely half that of 1993 (Dąbrowski 2004).

The collapse of economic growth in Georgia between 1991 and 1994 was caused by:

- rapid transition from a centrally planned economy to a market economy;

- rises in the prices of goods and services and the dollarisation of trade resulting from the end of cooperation with the former Soviet Union;

- suspension of production in heavy industry and its limitation in other branches $^{1}$ (Business Georgia 2012);

- a decline in demand for Georgian products and raw materials in the market of the former USSR; difficulty in acquiring new foreign markets;

${ }^{1}$ Compared to the level recorded for 1990 , production in Georgia had declined by $78 \%$ at the end of 1995. 
- loss of export revenue from Georgian agricultural products and raw materials; an increase in imports of goods not produced in Georgia, including corn and flour;

- use of industry for political ends and the involvement of employees in political activities;

- civil wars and wars of secession (Abkhazia and South Ossetia) contributed to the creation of a wave of refugees approximately 300,000 strong; their basic needs were a serious burden on the state budget;

- internal political conflict and weakening of power; a lack of means to implement reforms;

- a decline in the value of money and the emergence of hyperinflation.

In 1994-97, the GDP growth rate exceeded 10\% per year and Georgia became "one of the fastest recovering economies" (Business Georgia 2012). But a crisis in foreign trade ${ }^{2}$ immediately resulted in a fall in economic growth, which declined to almost zero in 1998-2000. Growth in GDP in this period was never higher than $3 \%$.

Despite some success due to reforms, the end of the $20^{\text {th }}$ century found the Georgian economy struggling with threats that included a low standard of living, an inefficient and corrupt bureaucratic apparatus, and unregulated ownership rights (Ekonomiczeskaya politika 2014).

Yet, with average GDP growth of 5.7\% in 2000-03 (Miedwiediew 2005), Georgia managed to relocate a positive economic direction as the $21^{\text {st }}$ century began. It is worth noting that by the end of 2003 the Georgian economy had managed to rebuild almost 70\% of the GDP value of 1991. The improvement in the economic situation could have been caused by:

- accelerated implementation of reforms developed with the International Monetary Fund ${ }^{3}$;

- an increase in exports due to the improved economic situation in the Russian Federation and Turkey (an increase in foreign trade, including an increase of $65 \%$ in exports);

- increased foreign $\mathrm{aid}^{4}$.

\footnotetext{
${ }^{2}$ The most critical factors were the currency crisis in the Russian Federation and the deterioration in the economy of Turkey, with whom Georgia had the strongest economic relations. In 1997, Georgia exported $27 \%$ of its exports to Russia and $20 \%$ to Turkey. The crises in Russia and Turkey led not only to a radical decline in Georgian exports to these countries, but also contributed to a significant fall in investor confidence in the economies of the region.

${ }^{3}$ In cooperation with the IMF, the government began to implement the Economic Development and Poverty Reduction Programme. Furthermore, in 2002 Georgia received a loan of USD 30 million from the IMF and USD 55 million from the World Bank.

${ }^{4}$ In 2001, the estimated value of foreign aid was USD 150 million.
} 
In spite of all the economic improvements, there was no significant change in living standards. In 2001, 54\% of people were living below the poverty line and unemployment had reached $17 \%$, while by 2002 per capita GDP (at purchasing power parity) had only reached USD 3,200 (Materski 2010; Dąbrowski 2004).

The takeover of power by Mikhail Saakashvili, which occurred as a result of the Rose Revolution, has led to major changes in the republic's economic policy. The priorities set by the new government included reducing the enormous budget deficit, accelerating privatisation, fiscal reform and combatting corruption (Materski 2010).

The changes that took place in 2003-10 led to the privatisation of 4,280 economic entities and a gain for the Georgian budget of USD 1.6 billion owing to the new ownership arrangements (Business Georgia 2012). A policy of expedited privatisation of state-owned businesses resulted in increased foreign direct investment. Privatisation and the inflow of foreign direct investment, which also contributed to creating the so-called fiscal effect (Jepifancew 2011) ${ }^{5}$ on Georgia's budget (Business Georgia 2012), were thus the major factors in GDP growth ${ }^{6}$ from the macroeconomic point of view.

Largely after 2003, Georgia carried out reforms in line with its IMF obligations entailing the reorganisation, liberalisation and simplification of trade regulations. This meant introducing lower rates of tax, reducing the number of forms of $\operatorname{tax}^{7}$ and overhauling tariff regulations ${ }^{8}$ (Jepifancew 2011). Moreover, because Georgia signed several trade contracts with its regional and other partners, business relations became more diverse, the investment environment improved, employment rules changed and mortgages became more accessible (Business Georgia 2012).

Furthermore, the aid received in May 2004 following the so-called donors' conference in Brussels, which decided to allocate multi-purpose aid of USD 1 billion, represented a significant financial injection that allowed for genuine structural reforms and modernisation at all levels. The US

\footnotetext{
5 In 2003-08, Georgia's budget income increased six-fold from USD 558 million in 2003 to USD 3.3 billion in 2008 .

${ }^{6}$ Georgia's GDP grew by $8.6 \%$ in 2006 and by $12.4 \%$ in 2007 . The republic received USD 1.2 billion in direct foreign investment in 2006 and USD 2.01 billion in 2007.

${ }^{7}$ At the same time as the tax system was being tightened, the twenty-two forms of fiscal burden were reduced to six and it was expected that by 2012 only four would remain.

${ }^{8}$ Simplified customs procedures were introduced and the amount of import tax on most products was reduced to zero or to a minimum level of $3-12 \%$.
} 
government also declared aid on a similar scale as part of the "Millennium challenges" initiative (Materski 2010).

With the completion of the Baku-Tbilisi-Ceyhan oil pipeline ${ }^{9}$ in 2005 and of the Baku-Tbilisi-Erzurum gas main in the following year, the transit of crude oil and natural gas from the Caspian Sea to the West through the republic became a major source of budget income.

A further goal adopted by the new government was the elimination of corruption. To this end it brought forward reforms that were surprisingly effective where the desired outcome was to improve and restructure the system with no financial input. Oligarchs, many of whom were arrested, had their finances and taxes thoroughly inspected and received severe fines. The far greater transparency of the new procedures and the halving of the number of taxation categories made it harder to commit this type of crime. The measures revived small and medium businesses and saw a more regular flow of tax income to the budget. More thorough and comprehensive inspections and rigorous penalties have curbed corruption considerably, which was reflected in Georgia's steady advance in Transparency International's corruption ranking (Materski 2010) from 89 2002 (Poczemu Gruzija 2007) to 55 $5^{\text {th }}$ in 2013 (Corruption Perceptions Index 2013). The country's notable achievements in the interim included $68^{\text {th }}$ place in 2008 (Indeks wosprijatija korrupcii 2009) and 66 $6^{\text {th }}$ place in 2009 (Corruption Perceptions Index 2009).

The economic structure of modern Georgia changed due to these transitions so that GDP now consists mainly of services $(64.9 \%)^{10}$, agriculture $(7.7 \%)^{11}$, industry $(16.8 \%)^{12}$ and construction (approximately 11.4\%) (National Statistics Office of Georgia 2012). From 2007, Georgia began to evolve from a country reliant on industry and agriculture to an economy of transit and services reliant on regional geo-economic projects. As a result of the completion of these projects, Georgia was obliged to commit to its role as a transit country and to perform communication functions (Ekonomika Gruzji 2010).

\footnotetext{
${ }^{9}$ The Georgian section of the Baku-Tbilisi-Ceyhan oil pipeline was officially opened on 12 October 2005. The first transport of oil took place in July 2006. The pipeline transports 1.2-1.3 million barrels of oil annually. See Ekonomiczeskaya politika (2014).

${ }^{10}$ The service sector (trade, transport, financial services, public administration, and security) accounts for over a third of employment in Georgia's economy.

${ }^{11}$ Agriculture employs half of all economically active citizens.

${ }^{12}$ Georgia's main industrial sectors are food and energy.
} 
Despite some achievements at the macroeconomic level, the republic was not able to solve the issues of poverty and unemployment. According to data from 2011, unemployment was running at 16.5\%. On the other hand, according to official data, the monthly cost of living in Georgia was USD 83.00 per person and $30 \%$ of people were living in poverty (RBC 2012). The authorities claimed that this problem would be partially solved through the development of tourism, which would allow new jobs to be created and increase incomes in certain regions of the country.

\section{The Role and Importance of Tourism in Modern Georgia}

The development of tourism in Georgia began in 1924 when the country was still a part of the former USSR and the authorities had begun to implement policies aimed at adapting new Georgian towns for resort-based tourism, which was not difficult because infrastructure remained from the previous era. With the building and refurbishment of sanatoria, and the erection of "chalets" for prominent party and state officials from Moscow - Stalin among them - the influx of patients and tourists grew steadily from 1925. By the end of the 1920s the towns of Tsqaltubo, Achani-Afoni, Java, Achtala and Bach had all become resorts (Materski 2010). By the time the 1960s had begun, Georgia, with its resorts and sanatoria, had become one of the major centres for rehabilitation and recuperation in the USSR. The inflow of funds for the construction of adequate infrastructure revived the Georgian economy and - especially in the western regions - tourism and wellness provided many new jobs (Materski 2010).

As was mentioned in the introduction, Georgia has tremendous assets as a tourist destination. It has more than 15,000 historical and cultural monuments, four of which are on the list of UNESCO World Heritage Sites: Mtskheta (Georgia's ancient capital), Bagrati Cathedral (11 ${ }^{\text {th }}$ century) and Gelati Monastery in Kutaisi (11 ${ }^{\text {th }}$ century), and Ushguli Village in Svaneti which, at 2,300 $\mathrm{m}$ above sea level, is the highest settlement in Europe. Turning to topography, the country offers the Caucasus Mountain range and the Black Sea coastline. The former, whose highest point is Mount Shkhara at 5,201 $\mathrm{m}(17,064 \mathrm{ft})$, has a number of peaks above 5,000 m, while the latter boasts 102 resorts (including three winter ones), 182 sanatoria and recreation areas, approximately 2,400 springs offering balneotherapy, karst caves, two active national parks, which are to be joined by a further seven, and 31 protected areas (Center for World Peace 2014). The warm, humid and near-subtropical climate of the Black Sea coast is similar to that of the 
Mediterranean, while further inland the climate is continental, with warm summers and cold winters. Snow and ice is present all year in the mountains at altitudes above $3,600 \mathrm{~m}(12,000 \mathrm{ft})$. These enduring assets are among the reasons why tourism played an important role in the creation of national income in Soviet times and continues to do so now in the latter-day, free republic.

Once independence had been secured, the government of modern Georgia identified tourism as an economic priority and strove to develop it in the following forms: business tourism, which could be provided based on its geographical location and a wide network of hotel brands (Radisson, Intercontinental, Holiday Inn), cultural tourism, religious tourism, winter sports, year-round mountain tourism, agro tourism, and wellness and adventure tourism (Rinkiaszwili 2013).

Numerous factors - not least political ones - have conditioned the trends in the development of tourism in Georgia. We are informed by data from 1988 that Georgia was being visited by four million tourists every year (Center for World Peace 2014), yet because of the outbreak of internal conflicts in Abkhazia and South Ossetia that number had dwindled to almost nothing by the early 1990s. The strife in these neighbouring countries caused hundreds of thousands of refugees to flee to Georgia where they were accommodated mainly in hotels and boarding houses. This meant that the greater part of the infrastructure that would otherwise have been available to tourists was occupied and led to the bankruptcy of the majority of hotels, spas and resorts (Dąbrowski 2004).

Another conditioning factor is internal political instability, which caused the country's image to suffer and thus created unfavourable circumstances for the development of tourism. These unpromising circumstances, in which resort tourism all but disappeared, prompted a decline in the tourist potential of Tbilisi and other historic cities of Georgia and led to the dominance of two types of tourism: summer on the Black Sea coast and winter in the mountain resorts of Bakuriani and Gudauri. Additional problems included the insolvency of society and the lack of a government social insurance programme (Rinkiaszwili 2013).

These difficulties arrested the growth of tourism, and of the Georgian economy as a whole, until 1995. It was then that the crisis prompted the government to pay more attention to the sector and take action to revive it. Eduard Shevardnadze, who was president at the time, said, "I must admit that the development of tourism is one of the priorities. It is an industry that brings measurable benefits faster than any other and contributes significantly 
to the regulation of the unemployment problem. No other industry is capable of solving this problem in such a timely manner" (Maslowa 2005).

After 2000-04 the economy entered a period of relative stabilisation thanks to the legalisation of private ownership, the creation of non-governmental and public organisations, and the strengthening of links with foreign countries. President Eduard Shevardnadze, in collaboration with experts from the US, Israel and the European Council, approved a "National Concept for the Development of Tourism" and recommendations and proposals made by the World Tourism Organisation were put forward during the Tbilisi International Forum "Tourism on the Great Silk Trail" in 1998 (Federal Post 2003).

The decision was taken to focus first of all on tackling the issues restraining the dynamic growth of tourism. Of these, restoring Georgia's image was considered the most pressing. It was not an easy task as the country lacked the funds to promote itself or to adequately research the tourist market, whose problems lay not only in the limited choice on offer to potential tourists but also in the low quality of tourist services. There was a shortage of qualified personnel in the industry, there were too few spaces in hotels during the high season, and there were a number of difficulties with transport, including insufficient flight connections linking existing and prospective tourist markets, an inflexible timetable, too few regional airlines, conflicts between airlines, and a poor road system (Center for World Peace 2014). Finally, given the military conflicts in the country and the lack of stability of the South Caucasus region, security was also an obstacle. Despite the many obstructions, there was slow but steady growth in the number of tourists visiting Georgia and in the income derived from them (Table 1) ${ }^{13}$.

A new trend was set in 2001 when Georgia received 302,000 tourists and visitors, which was four times the number that had visited in 1995 (Center for World Peace 2014). Driven by increased investment in infrastructure, including hotels and transport (RCB 2014), the trend was sustained and growth was at its highest in 2005, 2011 and 2012. There are a number of possible reasons for this. First, political and economic stability was recovered and this improved the country's image. Second, there was a government campaign abroad to promote tourism. Third, the sector benefitted from the changes to the tax law introduced from 2003. Georgia was visited by 5.4 million tourists in 2013 , which is an impressive result for such a small

${ }^{13}$ See: Elivagar (2014); Day Az (2005); Business Georgia (2009). 


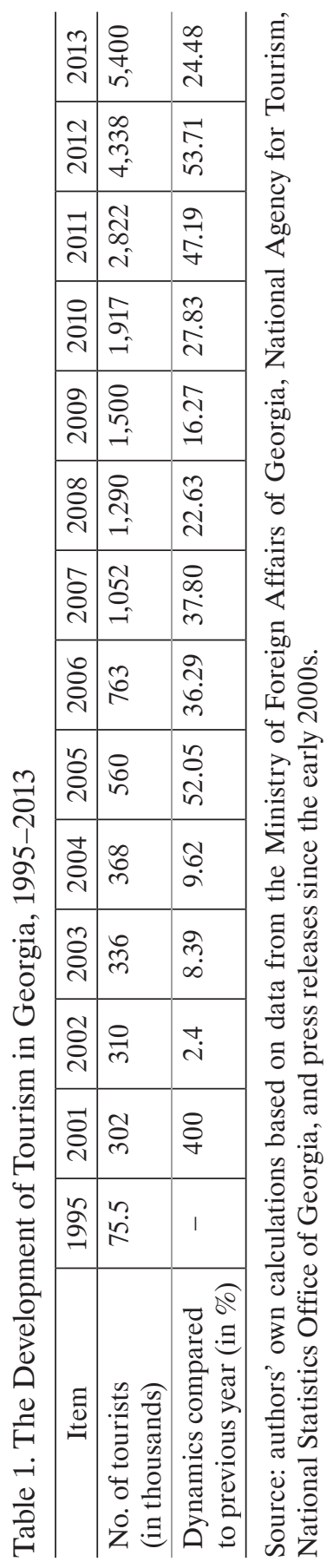


country. Most of the tourists came from Europe, which accounted for an average of 95\% of all visitors in 2005-12 (Table 2).

Table 2. Geographical Structure of International Tourism (\%)

\begin{tabular}{l|c|c|c|c|c|c|c|c}
\hline \multicolumn{1}{c|}{ Item } & 2005 & 2006 & 2007 & 2008 & 2009 & 2010 & 2011 & 2012 \\
\hline Europe & 95.2 & 95.24 & 95.95 & 96.38 & 96.49 & 96.3 & 95.49 & 95.42 \\
\hline Americas & 2.65 & 1.93 & 1.61 & 1.36 & 1.31 & 1.21 & 1.03 & 0.77 \\
\hline Asia and Pacific & 1.79 & 2.43 & 1.95 & 1.81 & 1.73 & 2.08 & 3.04 & 2.79 \\
\hline Africa & 0.08 & 0.07 & 0.09 & 0.05 & 0.07 & 0.17 & 0.15 & 0.16 \\
\hline Middle East & 0.17 & 0.19 & 0.24 & 0.25 & 0.22 & 0.17 & 0.20 & 0.39 \\
\hline Total & 100 & 100 & 100 & 100 & 100 & 100 & 100 & 100 \\
\hline
\end{tabular}

Source: authors' own calculations based on data from the National Agency for Tourism in 2013.

Tourists from the Asia-Pacific region were in second place, with a reported growth from 10,062 people in 2005 to 123,987 in 2012, while visitors from both the Americas, whose numbers reached 33,898 in 2012, were in third position. The growth in the number of tourists from the Middle East (17,141 in 2012) and Africa (7,110 in 2012) demonstrated that Georgia was also gaining popularity in those markets.

Most of the tourists that visit Georgia come from neighbouring countries. The source of the greatest increase in visitor numbers to Georgia in 200512 was Turkey. In 2005 Georgia received 109,000 visitors from that country. But by 2012 this figure had grown to 1.5 million visitors. In second place was Azerbaijan followed by Russia, Armenia and Ukraine. In total in 2012, Georgia was visited by almost three million tourists from neighbouring countries. It is also worth taking note of Israel where, as the figures given above show, the popularity of Georgia as a tourist destination increased in 2005-13. Georgia was also popular amongst citizens of the European Union - especially Poland - which was the source of a thirteen-fold growth in the number of tourists, Germany and Bulgaria (greater than four-fold growth), France (greater than three-fold growth) and the United Kingdom, Greece and the Netherlands (greater than two-fold growth). Of the countries beyond Europe, Georgia was popular amongst visitors from the US, Iran and the Philippines. According to National Tourism Agency data from 2012, the international travellers visiting Georgia had the following characteristics:

- holiday, leisure or recreation (40\%) are the commonest reasons given for a visit. Slightly more than a quarter of international tourists visit their 


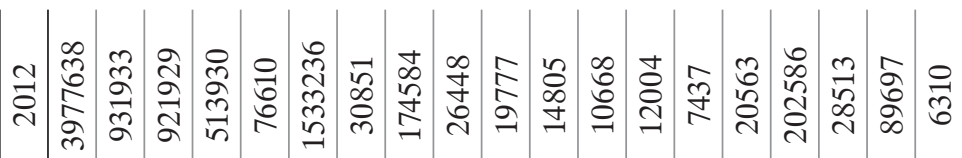

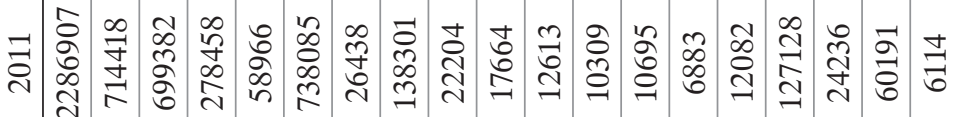

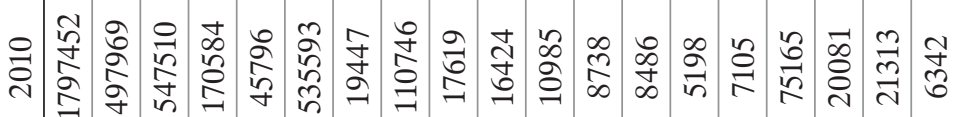

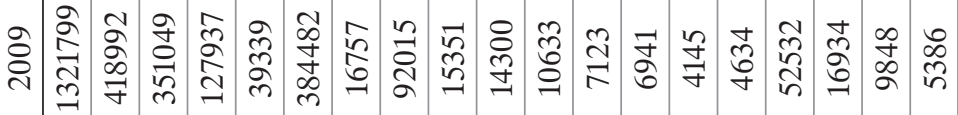

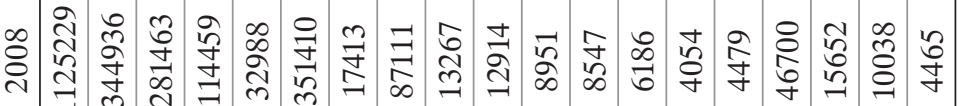

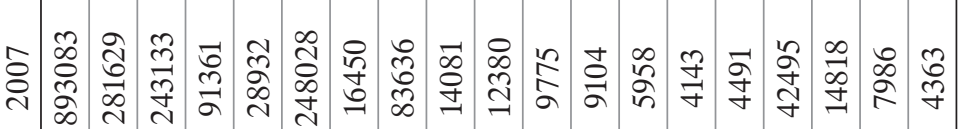

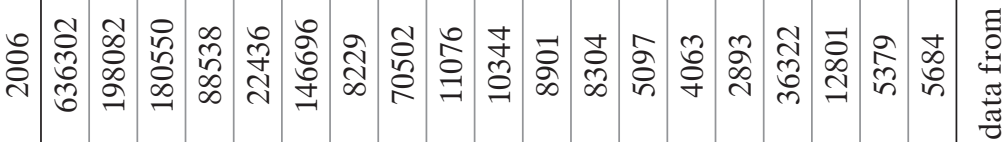

䓬

○

สำ

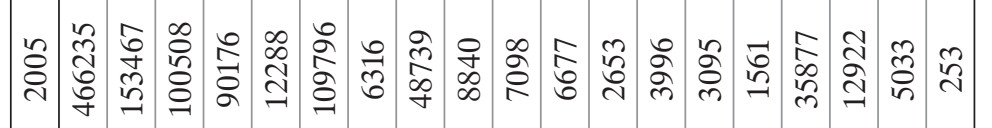

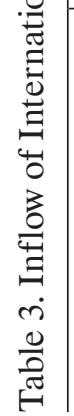

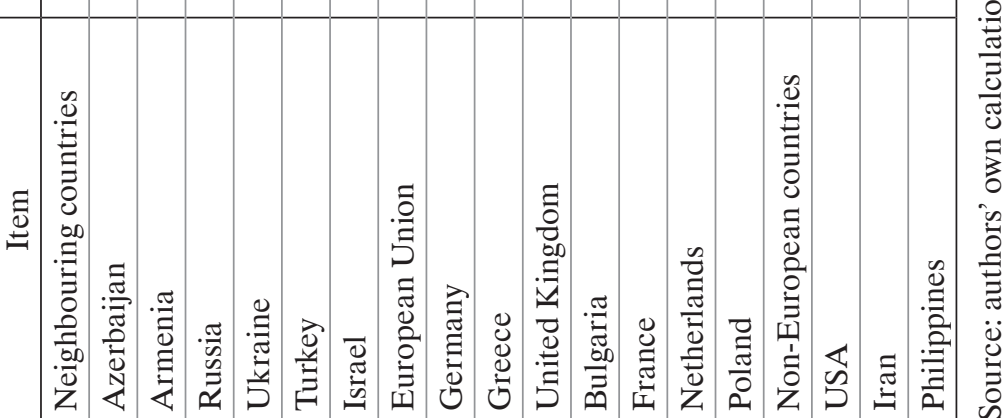


friends $(8 \%)$ or family $(17 \%)$. Only $8 \%$ travel for business purposes. Visitors also come to Georgia for shopping (7\%), transit (9\%) or other reasons $(12 \%)$;

- the average stay lasts nine days, while the median stay is two days;

- return visits account for $78 \%$ of arrivals, while $22 \%$ are first-time visitors;

- most of the travellers arrive overland by bus $(47 \%)$, car $(28 \%)$ and rented car $(5 \%)$. The next most popular choice is air transport (foreign airlines 12\%; Georgian Airlines 3\%). Rail and sea transport account for an insignificant share with $3 \%$ and $1 \%$ respectively;

- the top three activities are rest and relaxation (36\%), tasting Georgian dishes (35\%) and exploring Georgia's natural landscape (35\%);

- the most popular cities are Tbilisi and Batumi, which between them host $85 \%$ of all visitors (Tbilisi $45 \%$, Batumi $40 \%$ );

- more than a quarter of visitors $(27 \%)$ who came to Georgia did not spend the night there, but hotels were the most popular type of accommodation among visitors who did stay for a night or more (38\%). Approximately $33 \%$ of visitors stayed with friends or relatives in private apartments. International visitors took less frequent advantage of other types of accommodation: $11 \%$ stayed in private apartments and $8 \%$ chose guest houses. Rented accommodation proved satisfactory for $11 \%$ of international visitors, of which $6 \%$ rented rooms and $5 \%$ an entire apartment;

- almost half of international travellers (49\%) travelled alone, $22 \%$ with friends and $16 \%$ with family members;

- trips were planned by the travellers themselves in $70 \%$ of cases. Only $16 \%$ were organised by friends or family members and $8 \%$ by employers. At $1.4 \%$, the proportion of trips organised by travel companies was not significant;

- the average international visitor to Georgia spent GEL 546. The largest share, $23 \%$, was taken by eating out, drinks and shopping, while accommodation represented a slightly lower share of total spending at $18 \%$. Domestic transport accounted for $7 \%$ of overall spending in this category;

- the importance of tourism to the Georgian economy is reflected in the share of GDP contributed by profits from this sector. According to data from Georgia's National Statistics Office, tourism accounted for $7.3 \%$ of GDP in 2013, which represented growth of 1\% compared to 2012 (Tbilisskaya niedielia).

That tourism is a major source of income for the Georgian economy is illustrated by the quantitative data in Table 4 . 
Table 4. Profits of Georgian Tourism

\begin{tabular}{l|c|c|c|c|c|c|c}
\hline \multicolumn{1}{c|}{ Item } & 2007 & 2008 & 2009 & 2010 & 2011 & 2012 & 2013 \\
\hline $\begin{array}{l}\text { Profits from tourism } \\
\text { (million USD) }\end{array}$ & 3.838 & 446.646 & 475.889 & 659.245 & 954.908 & 809.202 & 730.00 \\
\hline $\begin{array}{l}\text { Average expenditure } \\
\text { of an international } \\
\text { tourist (in USD) }\end{array}$ & 3.65 & 346.21 & 317.25 & 324.48 & 338.34 & 182.74 & 135.18 \\
\hline
\end{tabular}

Source: authors' own calculations based on data from the National Agency for Tourism and press releases (Oragwielidze 2013).

The Georgian economy reported a notable increase in profits in 2007-11 due to an increase in the number of visitors. Following 2011, the number of tourists and visitors declined. It was observed, moreover, that the increase in the number of tourists and visitors in 2007-11 did not correlate with an increase in the average expenditure of individual tourists and visitors. There was a significant drop in the average expenditure of tourists and visitors in 2012, which was repeated in 2013, when the average expenditure of an individual tourist or visitor was only USD 135.18.

In spite of a fall in profits, one of the greatest economic successes of the republic was undoubtedly the increase in employment in tourism, which climbed from 17,000 in 2001 (Center for World Peace 2014) to 180,000 in 2013 (Oragwielidze 2013). The positive influence of tourism could also be seen in the field of goods and services, so that tourism is now the main or additional source of income for one in ten Georgians.

\section{The State's Role in the Development of Tourism}

The Georgian government declared the development of the tourism and hotel industry as one of its main priorities.

A large number of investment programmes were therefore launched to stimulate growth in the sector:

a) investors in hotels were offered the following benefits so that they could enter the Georgian market and be immediately competitive:

- access to the premier real estate properties through privatisation,

- purchase of privatised property by direct sale,

- significant discounts on current market value for privatised properties,

- land plots, greenfield projects and properties with suitable buildings for brownfield projects, 
- preferential terms from municipalities, such as Tbilisi and the regional centres;

b) special privileges through Free Tourist Zones in Kobuleti and Anaklia / Ganmukhuri. Investors making a commitment of between USD 1 million and USD 3 million in Kobuleti were offered free land, a free hotel master plan, a free casino license for hotels whose capacity exceeded 100 rooms, a fifteen-year exemption from profit and property taxes, and full utility and network provision with the corresponding outdoor infrastructure;

c) as well as entering the market as hotel owners through joint ventures and acquisitions, investors can also enter as hotel operators: there are many individual Georgian hotels interested in working with international operators as a way to increase revenues and occupancy rates;

d) given the gaps in supply, the market is open for hotel owners to make any form of new investment. Not only do hotel investors have access to prime real estate locations, they can also work with the Georgian government, and with the municipalities in places such as Tbilisi, to negotiate preferential terms;

e) a major reconstruction of tourist infrastructure is under way;

f) measures have been introduced to make travel easier, including by relaxing or removing visa requirements. Georgia now has a reciprocal, visa-free arrangement with 87 countries, including the US, Canada, and the member states of the European Union, whose citizens can all enter Georgia with only an ID card. Travellers from most other countries are issued visas on arrival;

g) the goal of improving service-quality is being pursued by providing intensive training to personnel in the tourism and hospitality industry throughout the country;

h) the Georgian National Tourism Administration is responsible for marketing, which undoubtedly plays a vital role in the growth of tourism.

The institutions vital to the development of tourism in Georgia are the president, the government, the Department of Tourism in the Ministry for the Economy and Stable Development, and the Georgian National Tourism Administration (GNTA). It is the latter institution that deserves the most attention. It was founded to increase the number of visitors and the amount of money they spend and so gain competitive advantage and increase market share, to encourage investors to invest and to support domestic private-sector development through effective public and private partnership. This was to be achieved by improving the country's image, creating brand identity, positioning the country on the international tourist map, promoting it as an 
undiscovered and unique travel destination and improving visitor experience by developing infrastructure, improving service quality, improving the quality of training and supporting and implementing product development. Taken as a whole, these measures would result in a rise in the numbers employed in tourism and a significant boost to the Georgian economy.

The GNTA aims to actively implement state policy to raise awareness of Georgia's tourism sector on the global playing field. This involves stimulating the growth of inbound and domestic tourism, assisting in the creation of a friendly environment for tourism businesses, raising the country's competitiveness on the international tourism market, promoting a welcoming image and forging a powerful brand. The GNTA's priorities are:

- to promote Georgia as a tourist destination through various marketing activities such as exhibitions, press tours and advertising campaigns,

- to develop the skills of tourism personnel and thus improve customer service in the sector,

- to package natural and cultural tourist attractions as tourist products,

- to develop a nationwide tourism infrastructure,

- to develop high standards for tourism products,

- to encourage competitiveness through compliance with fair product pricing and quality.

The measures introduced by the GNTA to increase the number of visitors include making international travel easier, improving service quality, targeting new markets and developing tourist products. The body's wide-ranging tasks include conducting extensive marketing and promotional campaigns at home and abroad, arranging press and FAM trips, attending international travel-fairs, producing printed materials, and marketing via social media.

The government invests a great deal of importance in ensuring that tourism enjoys vigorous growth and is striving to make it one of the main branches of the economy. According to the head of the National Tourism Agency, Giorgi Sigua, this can be accomplished by gaining adequate support from the government and collaborating with international organisations and the private sector. To lend cohesion to the combined initiatives a council was established within the National Agency for Tourism on 20 February 2013, which included the Georgian Travel Association, the Tourist Guides Society, the Association of Tourist Companies and the Association of Employment Agencies (Business Georgia 2013b). Collaboration of this kind will allow more services to be provided and favour the dynamic development of tourist 
infrastructure. Advances in online marketing are also essential to the growth of tourism and the streamlining of tourist administration (Business Georgia 2013c).

Georgia was very active from the early 2000s in strengthening cooperation on tourism and concluded agreements with a number of countries in this field. One example was a tourism-cooperation agreement signed on 19 October 2010 during a visit made by the Georgian Minister for the Economy to Israel. It was hoped that it would stimulate tourist traffic between the two countries, improve the work and performance of airlines operating flights to Tel-Aviv and Tbilisi and remove bureaucratic obstacles inhibiting the development of bilateral relations, "Georgia, like its neighbours, the countries of the CIS, may become a significant source of 'supply' of visitors to Israel. This is why, when the visa-free regime is introduced between Israel and Ukraine, we want to initiate a similar process with Georgia. This will not only contribute to positive 'tourist' results, but also to political results" said Israel's minister of tourism, Stas Misezhnikov (Business Georgia 2010).

Georgia signed further tourism-cooperation agreements on 10 July 2013 with Serbia (Georgia Online 2013) and at the beginning of the following month with Estonia during the official visit made to Tallinn by Georgian Prime Minister Bidzina Ivanishvili (Business Georgia 2013a). The signing of a similar agreement between Georgia and Armenia was planned for 2014 (Żohowurd 2014). As a consequence of this sort of international cooperation it is predicted that the number of visitors to Georgia will continue to grow. Experts believe that the industry earn more income and create new jobs in the period to 2017 (Euromonitor 2012).

Tbilisi was chosen to host the 2015 edition of the Youth Olympic Festival, which is an important global sporting event. The festival was expected to attract some 4,000 athletes from 49 European countries and more than 10,000 visitors. However the accommodation available when the event was announced was insufficient to meet the expected demand. To remedy this, the government undertook to make improvements in the general and sporting infrastructure of the city, which in the latter case meant renovations to bring facilities up to European standards and the construction of a village for the athletes. In this same year Georgia will, for the first time, host the UEFA Super Cup (Euromonitor 2012). 


\section{Summary}

Tourism, which is Georgia's main source of income, has played an important role in the country's economy since the early 2000s. According to data published by the World Economic Forum, Georgia now holds $73^{\text {rd }}$ place out of 139 countries in the ranking of the most competitive countries in the tourism sector, while in the European ranking of 42 countries it lies in $36^{\text {th }}$ place. It is nine places ahead of Armenia and Azerbaijan and, on average, 12 places behind Russia and Turkey. At the regional level, Georgia enjoys advantages with regard to its regulatory regime for tourism, its stability, security, and human capital. According to these indicators, Georgia is 27 places ahead of all of its neighbours. When compared with Russia on human, cultural and, especially, natural resources, however, Georgia lags behind: that Russia outperforms Georgia in these categories is, in fact, almost entirely on account of differences in natural resources. Georgia also trails Turkey in the category of cultural resources.

The analysis indicates that the choice made by modern Georgia to develop inbound foreign tourism has already led to considerable progress and will see even more intense development in the future. For a country like Georgia, hosting popular sporting events could become a powerful tool for destination marketing and represent a tremendous opportunity to promote the country and improve its image (Euromonitor 2012).

Conclusions drawn regarding the socio-economic consequences of the development of tourism for Georgia could have implications for post-Soviet states such as Moldova, Ukraine, Kazakhstan and Uzbekistan, which have been unable to shake off economic depression even though the transformation period has nominally ended. It would seem reasonable to suggest that the status quo can be changed if the combined efforts of the state, economic organisations, and entrepreneurs are properly focussed on developing international tourism.

It is important, though, not to forget the importance of domestic tourism when discussing international tourism. Here again the government has a role to play in creating the socio-economic conditions in which Georgians will regain their enthusiasm for their own tourist attractions. While Georgia's international tourist economy, which is likely to develop with increased dynamism, warrants continued monitoring, there is also a case for a particularly close study of Georgia's domestic tourist economy, which it appears may soon enjoy a resurgence. 


\section{Bibliography}

Business Georgia (2009) "Probliemy turisticzeskogo biznesa w Gruzii”. http://bizzone. info/articles/1238611960.php. Accessed: 12 February 2014.

Business Georgia (2010) "Izrail' podpisal z Gruzijej soglaszenije o sotrudniczestwie w sfierie turizma”. http://bizzone.info/tourism/2010/1287533412.php. Accessed: 18 February 2014.

Business Georgia (2012) "Ekonomiczeskaya transfromacyja Gruzii: 20 liet niezawisimosti”. http://bizzone.info/articles/1341447059.php. Accessed: 15 January 2014.

Business Georgia (2013a) "Gruzija i Estonia podpisali soglaszenie o wzaimopomoszczi w sfierie turizma”. http://bizzone.info/tourism/2013/1378771674.php. Accessed: 18 February 2014.

Business Georgia (2013b) "Ministierstwo ekonomiki i turisticzeskije associaciji sformirowali sowietnikow". http://bizzone.info/tourism/2013/1361395097.php. Accessed: 18 February 2014.

Business Georgia (2013c) “Turizm dolzen stat' odnim iż wieduszczyh oraslej ekonomiki - Gieorgij Sigua”. http://bizzone.info/tourism/2013/1372101258.php. Accessed: 8 December 2013.

Center for World Peace (2014) Riegionalnaja Ekonomiczeskaja Raboczaja Grupa pod lidierstwom amierikanskogo Uniwiersitietskogo Centra Globalnogo Mira, Gruzija. Obzor po stranie, podgotowlien soglasno rukowodiaszczym princypam dla Armianskih-Azierbajdżanskih-Gruzinskih-Turieckih grupp issliedowanija biznes klimata, Podgotowlien Gruzinskim Centrom Ekonomiczeskoj Politiki i Zakonodatielstwa. pp. 15-16.

Corruption Perceptions Index (2009) http://archive.transparency.org/policy_ research/ surveys_indices/cpi/2009/cpi_2009_table. Accessed: 12 February 2014.

Corruption Perceptions Index (2013) http://www.transparency.org/cpi2013/results. Accessed: 12 February 2014.

Day Az (2005) "Osnownoj zadaczej turisticzeskoj otrasli Gruziii jawliaietsia formirowanieje imidza strany - Minekonomiki”. http://news.day.az/georgia/18626. html. Accessed: 18 February 2014.

Dąbrowski, K. (2004) Etapy rozwoju gospodarczego Gruzji w latach 1801-2004. [Stages of Georgia's economic growth, 1801-2004]. Inter-departmental Studies in Mathematics and Natural Sciences. Warsaw: Warsaw University, pp. 22, 27-28.

Ekonomiczeskaya politika (2014) "Ekonomiczeskaya politika sowriemiennoj Gruzii". http://www.memoid.ru/node/Ehkonomicheskaya_politika_sovremennoj_Gruzii. Accessed: 15 January 2014.

Ekonomika Gruzii (2010) “Ekonomika Gruzii”. http://newsruss.ru/doc/index.php/\%D0 $\% \mathrm{AD} \% \mathrm{D} 0 \% \mathrm{BA} \% \mathrm{D} 0 \% \mathrm{BE} \% \mathrm{D} 0 \% \mathrm{BD} \% \mathrm{D} 0 \% \mathrm{BE} \% \mathrm{D} 0 \% \mathrm{BC} \% \mathrm{D} 0 \% \mathrm{~B} 8 \% \mathrm{D} 0 \% \mathrm{BA} \%$ D0\%B0_\%D0\%93\%D1\%80\%D1\%83\%D0\%B7\%D0\%B8\%D0\%B8\#cite_note-12. Accessed: 12 February 2014.

Elivagar (2014) “W Gruzii otieliej bolsze, a turistow mien'sze”. http://elivagar.by/novostiturizma-gruzii/v-gruzii-otelejj-bolshe-a-turistov-menshe.html. Accessed: 18 February 2014. 
Euromonitor (2012) http://www.euromonitor.com/travel-and-tourism-in-georgia/report. Accessed: 18 February 2014.

Federal Post (2003) "Szewarnadze: Gruziju spasiet turizm". http://fedpost.ru/ sobytiya/10673-shevardnadze-gruziyu-spaset-turizm.html. Accessed: 12 February 2014.

Georgia Online (2013) “Gruzja i Serbija podpisali soglaszenie o sotrudniczestwie w sfierie turizma”. http://www.apsny.ge/2013/pol/1373513501.php. Accessed: 19 February 2014.

Geostat (2014) http://geostat.ge/index.php?action=0\&lang=eng. National Statistics Office of Georgia. Accessed: 20 March 2014.

GNTA (2012) Georgian Tourism Industry Overview. Tbilisi: Georgian National Tourism Administration, p. 6.

Gruzija (2014) “Gruzija”. http://igras.ru/strana.php?r=36\&id=94. Accessed: 18 February 2014.

Indeks wosprijatija korrupcii (2009) http://rating.rbc.ru/articles/2008/09/30/32143675_tbl. shtml?2008/09/30/32143608. Accessed: 12 February 2014.

Jepifancew, A. (2011) "Rieformy w Gruzii. Analiz gruzinskih reform. Primienimy li oni w Rossii?” http://www.apn.ru/publications/article23547.htm. Accessed: 9 February 2014.

Maslowa, A. (2005) Turizm w Gruzii [Tourism in Georgia]. Taszkientskij professionalnyj kolledż gostinicznogo hoziaystwa. http://www.docme.ru/doc/190834/turizm-gruzii. Accessed: 18 February 2014.

Materski, W. (2010) Gruzja [Georgia]. Warsaw: Trio, pp. 154, 231, 327-28, 347-48.

Miedwiediew, R. (2005) "Ekonomika stran Sodru żertwa. Na raznych skorostiah i po raznym dorogam. K postanowkie problemy". Ekonomiczeskije stratiegii 8. http://www. inesnet.ru/magazine/mag_archive/free/2005_08/medvedev.htm. Accessed: 4 February 2014.

Mitręga, D. and Pietrucha, J. (2004) Gruzja [Georgia] in S. Swadźba (ed.) Systemy gospodarcze krajów bytego ZSRR [Economic systems of the post-Soviet countries]. Katowice: Academy of Economics.

National Statistics Office of Georgia (2012) "National Accounts of Georgia 2012”. Tbilisi, p. 22.

Oragwielidze, I. (2013) “Turpotok rastiet, dohody padajut". http://www.ekhokavkaza. mobi/a/25207758.html. Accessed: 19 February 2014.

Poczemu Gruzija (2007) "Poczemu Gruzija?". http://www.traccc.cdn.ge/rus/about/index. html. Accessed: 12 February 2014.

RBC (2012) "Gruzija lidirujet po urowniu bezraboticy w riegionie”. http://www.rbc.ru/ rbcfreenews/20120516155132.shtml. Accessed: 22 November 2013.

RCB (2014) "Gruzja - kraj rosnących możliwości”. http://www.rcb-olsztyn.pl/files/gruzjaopracowanie_rynkowe.pdf. Accessed: 18 February 2014.

Rinkiaszwili, N. (2013) "Probliemy i pierspiektiwy razwitija turizma w Gruzii". http:// www.ysu.am/files/11N_Rinkiashvili.pdf. Accessed: 12 December 2013, pp. 73-74.

Tbilisskaya niedielia (2014) "Dolia turizma w WWP Gruzii uwieliczilas' na 1\%". Informacyonnyj portal Tbilisskaya niedielia. http://www.georgianpress.ru/economicss/ 19604-dolya-turizma-v-vvp-gruzii-uvelichilas-na-1.html. Accessed: 22 November 2013.

Trading Economics (2014) "Gruzja - inflacja" [Georgia - inflation]. http:// pl.tradingeconomics.com/georgia/inflation-cpi. Accessed: 30 January 2014. 
Wiellisz, W. (1996) Georgia. A Brief Survey of Macroeconomic Problems and Policies. Warsaw: CASE.

Żohowurd (2014) “Gazieta 'Żohowurd': Mieżdu Armienijej i Gruzijej budiet podpisano soglaszenie o sotrudniczestwie w sfierie turizma". http://www.tert.am/ru/ news/2014/02/05/joghovurd6/. Accessed: 19 February 2014.

\section{Abstract}

\section{Turystyka jako priorytet rozwoju gospodarczego współczesnej Gruzji}

Od przełomu lat 90. XX w. i pierwszej dekady XXI w. Gruzji coraz bardziej zależy na odrodzeniu i rozwoju turystyki. Obrany przez nią kierunek rozwoju gospodarczego jest zasadny, ponieważ kraj ten posiada duże walory turystyczne. Celem artykułu jest ukazanie roli i znaczenia turystyki we współczesnej Gruzji. Obecnie turystyka jest ważnym czynnikiem politycznej i międzynarodowej integracji. Fakt ten został dostrzeżony przez władze współczesnej Gruzji i od 2000 r. w rozwoju tego sektora rząd republiki upatruje możliwość wejścia państwa na ścieżkę wzrostu gospodarczego. Podsumowując rolę i znaczenie turystyki w systemie gospodarczym Gruzji, należy stwierdzić, że od początku XXI w. jest ona znaczącym źródłem dochodu narodowego.

Słowa kluczowe: Gruzja, turystyka, rozwój ekonomiczny, rozwój turystyczny. 